\title{
Black Soldier Fly (Hermetia illucens) Larvae and Prepupae Defatted Meals in Diets for Zebrafish (Danio rerio)
}

\author{
Carlos F. C. Lanes ${ }^{1}{ }^{\circledR}$, Fabio A. Pedron ${ }^{1}$, Giovani T. Bergamin ${ }^{1}$, Andressa L. Bitencourt ${ }^{1}$, Brenda E. R. Dorneles ${ }^{1}$, \\ Jessica C. V. Villanova ${ }^{1}$, Kimberly C. Dias ${ }^{1}$, Kristian Riolo ${ }^{2}$, Sabrina Oliva ${ }^{2}$ (D) , Domenico Savastano ${ }^{3}$ (1) \\ and Alessia Giannetto ${ }^{2, *(1)}$
}

1 Curso Superior de Tecnologia em Aquicultura, Campus Uruguaiana, Federal University of Pampa, Uruguaiana, Rio Grande do Sul 118, Brazil; carloslanes@unipampa.edu.br (C.F.C.L.); fabiopedron@unipampa.edu.br (F.A.P.); giovanibergamin@unipampa.edu.br (G.T.B.); andressabitencourt.aluno@unipampa.edu.br (A.L.B.); brendadorneles.aluno@unipampa.edu.br (B.E.R.D.); jessicavillanova.aluno@unipampa.edu.br (J.C.V.V.); kimberlydias.aluno@unipampa.edu.br (K.C.D.)

2 Department of Chemical, Biological, Pharmaceutical and Environmental Sciences, University of Messina, Viale F. Stagno d'Alcontres n. 31, 98166 Messina, Italy; kristian.riolo@unime.it (K.R.); soliva@unime.it (S.O.)

3 Progetto Hermetia, 89013 Gioia Tauro, Italy; domenicosavastano@hotmail.it

* Correspondence: agiannetto@unime.it

check for updates

Citation: Lanes, C.F.C.; Pedron, F.A.; Bergamin, G.T.; Bitencourt, A.L.; Dorneles, B.E.R.; Villanova, J.C.V.; Dias, K.C.; Riolo, K.; Oliva, S.; Savastano, D.; et al. Black Soldier Fly (Hermetia illucens) Larvae and Prepupae Defatted Meals in Diets for Zebrafish (Danio rerio). Animals 2021, 11, 720. https://doi.org/10.3390/ ani11030720

Academic Editors: Alessia Giannetto, Basilio Randazzo and Ellen S. Dierenfeld

Received: 4 February 2021

Accepted: 2 March 2021

Published: 6 March 2021

Publisher's Note: MDPI stays neutral with regard to jurisdictional claims in published maps and institutional affiliations.

Copyright: (c) 2021 by the authors. Licensee MDPI, Basel, Switzerland. This article is an open access article distributed under the terms and conditions of the Creative Commons Attribution (CC BY) license (https:/ / creativecommons.org/licenses/by/ $4.0 /)$.
Simple Summary: Aquaculture accounts for 52\% of the world's production of fish for human consumption and its growth relies on finding new alternative protein sources to fishmeal to use in aquafeeds. To make fish feed more sustainable, insects have emerged as valuable alternatives due to their high nutritional value. In this context, black soldier fly (BSF) meals have been used to replace, partially or totally, fishmeal in aquafeeds. However, due to relevant nutritional peculiarities of BSF developmental stages, it is crucial to understand how they can affect fish growth performance and health status. In this study, we evaluated the effects of total dietary replacement of fishmeal with defatted BSF larvae and prepupae meals on the growth performance of zebrafish from larva, through adult stages, in a 60-day feeding trial. Moreover, the effects of the two BSF meals on the expression of genes involved in growth, stress- and immune- responses, as well as hydrolysis of chitin were investigated. Overall, our results showed the beneficial role of defatted BSF meals in zebrafish diet, especially regarding prepupae meal, suggesting that black soldier fly meals could totally replace fishmeal without negatively affecting growth and wellness of zebrafish.

\begin{abstract}
The black soldier fly (BSF) Hermetia illucens is receiving increasing attention as a sustainable fishmeal alternative protein source for aquaculture. To date, no studies have explored the effects of fishmeal replacement with BSF V instar larvae or prepupae meals due to their peculiar nutritional properties on fish performances. This study investigated the effects of $100 \%$ replacement of fishmeal (control diet) with defatted BSF meals (V instar larvae and prepupae meals, treatments) on growth performance and welfare of zebrafish (Danio rerio), from larvae to adults, in a 60-day feeding trial. Following the inclusion of BSF meals, the expression of key genes involved in growth (igf1, igf2, mstnb, myod1, myog, myf5), hydrolysis of chitin (chia.2, chia.3, chia.5), immune- (il1b, il6, tnf $\alpha$ ), and stress- (hsp70 and $n r 3 c 1$ ) responses, as assessed by qPCR, was modulated in all of the molecular pathways, except for the stress response. Overall, our findings showed that both BSF meals can totally replace fishmeal without adverse impacts on adult zebrafish growth parameters (final total and standard length, final body weight, weight gain, daily growth rate, specific growth rate) and welfare, with BSF prepupae meal inducing the most beneficial effects, thus suggesting their potential application to meet fish requirements in aquaculture.
\end{abstract}

Keywords: aquaculture; insect meal; Hermetia illucens; gene expression; chitin; fishmeal; fish wellness 


\section{Introduction}

Over the last three decades, the aquaculture industry has been the world's fastest growing food-producing sector. In 2018, aquaculture production reached 82.10 million tons, representing $52 \%$ of the world's fish used for human consumption [1]. The future growth of aquaculture relies on the finding of sustainable alternative protein sources to use in aquafeeds. Fishmeal has been largely used as one of the primary protein source for farmed fish feeds due to its highly digestible protein, properly balanced amino acids profile, good palatability, as well as, deficient in the anti-nutritional factors [2,3]. However, both environmental and economic (decreased availability and increased cost) concerns increase the urgent need to replace fishmeal for sustaining the further development of aquaculture. Currently, plant-based proteins (especially soybean meal) and processed animal proteins (PAPs) from non-ruminant animals (poultry and pigs) are used as ingredients in formulated fish feeds, to meet the fish's nutritional requirements for their good digestibility and palatability, lower carbon footprint and reduced levels of anti-nutritional factors than vegetable products, which improves fish health and welfare. Among the fishmeal alternative protein sources, PAP from insect species has been gaining increasing attention for the valuable nutritional properties of insect larvae meals [4].

Recently, the European Commission (Regulation 2017/893/EC) approved seven species of insects to be used in aquafeeds: housefly ( $\mathrm{Musca}$ domestica), black soldier fly (Hermetia illucens), beetles (Tenebrio molitor and Alphitobius diaperinus), and crickets (Ancheta domesticus, Gryllodes sigillatus, and Gryllus assimilis). In 2018, the United States released the use of black soldier fly as food for salmonids [5].

The production of insects as protein source for aquafeeds shows a series of interesting and eco-friendly characteristics. For example, insects can efficiently bioconvert low-grade organic substrates into high-quality protein. They do not require arable land, which allows the production of protein in infertile or degraded soils. They do not compete with human food sources or human food production. They have short life cycles and can grow on a wide range of substrates with high productivity. They have low demand for water and energy when compared to other livestock; and insects have a low risk of transmitting zoonotic infections [4,6-8].

Among the promising insect species investigated as alternative nutrient sources for aquafeeds, so far, the black soldier fly (BSF) has been identified as a suitable candidate. Previous studies have assessed the effects of fishmeal replacement (partial or total) with BSF meals in aquafeeds [9-13]. Although BSF inclusion in fish diets has shown favorable results, no scientific reports established the most suitable BSF larval stage to be used as feed until now. Recently, relevant differences in the proximate composition of BSF V instar larvae and prepupae, in terms of both fatty acid and amino acid profiles, as well as minerals and vitamins, have been demonstrated [14-16]. In addition, Huyben et al. [17] evaluated the differences in gut microbiota of rainbow trout (Oncorhynchus mykiss) fed with BSF larvae or prepupae, demonstrating that the gut bacteria composition in this species is also influenced by the developmental stage of the insect used as meal.

Zebrafish (Danio rerio) has been widely used as an experimental model in several areas, including neurosciences, toxicology, genetics, embryology, metabolism, and oncology. In aquaculture field, zebrafish has been used in nutritional studies as an ideal alternative to commercial fish species for preliminary assessments of different novel ingredients late suggested as suitable for aquafeeds [18]. Moreover, zebrafish has been considered as an ideal platform for nutritional genomic studies due to the availability of a wide range of molecular tools [19].

The present study aimed to investigate the effects of total dietary replacement of fishmeal with defatted BSF larvae and prepupae meals on zebrafish growth performance and welfare. The expression of key genes involved in fish growth (igf-1, igf-2, mstnb, myod1, myog, myf5), enzymatic hydrolysis of chitin (chia.2, chia.3, chia.5), immune (il1b, il6, tnfo), and stress responses ( $h s p 70$ and $n r 3 c 1$ ) was evaluated to understand the physiological and molecular responses to the inclusion of BSF meals in the zebrafish diet. Such information 
might be helpful to select the most suitable BSF developmental stage for future inclusion of BSF in the aquafeeds.

\section{Materials and Methods}

\subsection{Insect Source}

Specimens of Hermetia illucens were bred and collected from an established colony (www.progettohermetia.it) (Gioia Tauro, Italy). After hatching, BSF larvae were put on a mix of flour (35\%) and water (65\%) for 5 days and then reared on organic waste composed of a mix of vegetable and fruit wastes ( $40 \%$ pears, $45 \%$ banana, $5 \%$ tomatoes, $10 \%$ various leafy green vegetables, $\% w / w$ on fresh weight basis) as described by Giannetto et al. [15]. The substrate was ground with a $3 \mathrm{~mm}$ die meat mincer (Fama Industrie, Rimini, Italy) before being used to feed the larvae. The $\mathrm{V}$ instar larvae and prepupae were recognized following established criteria by Kim et al. [20] and Tomberlin et al. [21]. The V instar larvae and prepupae samples were collected and set at $4{ }^{\circ} \mathrm{C}$ to allow quiescence to be reached. Samples were dried at $55{ }^{\circ} \mathrm{C}$ in a ventilated oven (TE-394/2-MP, Tecnal, Piracicaba/SP, Brazil) until a constant weight and ground. The proximate composition of $\mathrm{V}$ instar and prepupae was previously reported in Giannetto et al. [15].

\subsection{Experimental Diets}

Dried V instar larvae and prepupae samples were crushed and defatted with hexane ( $4 \mathrm{~L}$ of reagent to $1 \mathrm{~kg}$ of material). After $30 \mathrm{~min}$, hexane was removed and the material was dried during $24 \mathrm{~h}$ at room temperature $\left(\cong 20^{\circ} \mathrm{C}\right)$. Afterwards, the samples and all ingredients were milled in a small size hammer mill and sieved using a $150 \mu \mathrm{m}$ mesh sieve.

Experimental diets are shown in Table 1. The diets were formulated to be isonitrogenous and isolipidic, according to zebrafish requirements [22]. The control diet (Ctr) contained fishmeal (processing residue) as a main protein source. In the other two experimental diets, fishmeal was replaced with $100 \%$ of defatted V instar larvae meal (V instar) or with $100 \%$ defatted prepupae meal (prepupae). To prepare the experimental feeds, the milled dry ingredients $(<150 \mu \mathrm{m})$ and oils were thoroughly mixed manually. Water was added to the mixtures to attain an appropriate consistency for pelleting. The feeds were pressed through a meat grinder (PBM10I, Beccaro, Rio Claro/SP, Brazil) that had a $3.5 \mathrm{~mm}$ die and dried at $50{ }^{\circ} \mathrm{C}$ for $24 \mathrm{~h}$ in a ventilated oven (TE-394/2-MP, Tecnal, Piracicaba/SP, Brazil) and subsequently stored at $4{ }^{\circ} \mathrm{C}$.

Table 1. Formulation $\left(\mathrm{g} \mathrm{Kg}^{-1}\right)$ and proximate composition * of experimental diets.

\begin{tabular}{cccc}
\hline Ingredients & Control & V Instar & Prepupae \\
\hline Fish meal & 500 & - & - \\
Defatted V instar larvae meal & - & 500 & - \\
Defatted prepupae meal & - & - & 500 \\
Soy protein concentrate & 250 & 148.8 & 200 \\
Soybean meal & 140 & 241.2 & 190 \\
Canola oil & 40 & 40 & 40 \\
Defatted rice meal & 30 & 30 & 30 \\
Vitamin/MineralPremix & 30 & 30 & 30 \\
Salt & 10 & 10 & 10 \\
Proximate composition (\%) & & & 46.92 \\
Crude protein & 46.43 & 45.39 & 9.13 \\
Crude lipid & 9.40 & 9.70 & 9.01 \\
Ash & 22.19 & 9.16 & 18.50 \\
NFE & 13.86 & 24.11 & 13.60 \\
Chitin & 8.12 & 11.64 & 7.22 \\
Acid detergent fiber & & 6.31 & 93.30 \\
- & 94.53 & 92.69 & 18.57 \\
Groster & & & 25.27 \\
Protein $/$ energy (g/MJ) & 17.09 & 18.74 & 24.22 \\
\hline
\end{tabular}

* Analyzed values; ${ }^{1}$ Nitrogen Free Extract $=100-(\%$ Crude Protein $+\%$ Crude Fat $+\%$ Crude Fiber $+\%$ Moisture $+\%$ Ash); ${ }^{2}$ Gross Energy $\left(\mathrm{MJ} \mathrm{Kg}^{-1}\right)=0.0236$ Crude protein +0.0393 Crude lipid +0.0174 Nitrogen free extract. 
The proximate nutrient composition in the final feeds was analyzed to inspect whether the nutrient composition was as expected, based on calculations (Table 1). Dry matter, ash, and protein content were determined according to Association of Official Analytical Chemists AOAC [23]. Total fat content was determined gravimetrically following the method of Bligh and Dyer [24]. Acid detergent fiber (ADF) was determined by the method of Van Soest et al. [25]. The chitin content was estimated by calculating the acid detergent fibers (ADFs) and subtracting to this value the amino acids (by weight) contained in the ADF residue (\%), as described by Finke [26]. All of the chemical analyses were carried out in triplicate.

\subsection{Fish Feeding Trial and Growth Analysis}

Eggs of zebrafish were obtained from a broodstock maintained at the Laboratory of Ornamental Fish from Federal University of Pampa-Campus Uruguaiana under the conditions described by Westerfield [27]. At 30 days post-hatching (dph), larvae (5.0 $\pm 0.5 \mathrm{mg}$; $9.2 \pm 0.3 \mathrm{~mm}$, mean \pm standard error) were randomly distributed in twelve $4 \mathrm{~L}$ tanks (25 larvae per tank), with four replicate tanks for each treatment (Ctr, V instar, and prepupae) in a recirculating water system. Water temperature and dissolved oxygen were monitored daily while other water quality parameters were monitored weekly. Temperature was kept at $27 \pm 0.3{ }^{\circ} \mathrm{C}, \mathrm{pH}=8.1 \pm 0.1$, dissolved oxygen $=6.4 \pm 0.12 \mathrm{mg} / \mathrm{L}$ and 12L:12D photoperiod.

Fish were fed with experimental diets three times a day (8:00 a.m., 12:00 p.m., and 5:00 p.m.) for 60 days ad libitum. The tanks were siphoned once daily at 11:00 a.m. and the water was replenished. From days 0 to 15 , fish were fed with food particle size $<150 \mu \mathrm{m}$. From days 16 to 35, fish were fed with food particle size 150-250 $\mu \mathrm{m}$. Thereafter, fish were fed with food particle size 300-400 $\mu \mathrm{m}$. The total biomass in each tank was evaluated to each 15 days to evaluate the growth. For this, all fish were anesthetized with eugenol $(60 \mathrm{mg} / \mathrm{L})$ [28]. During the experiment, the dead fish were removed and recorded for calculating the survival rate. The survival rate was calculated considering the remaining individuals in each tank, discounting the two fish that were sampled in the middle of experiment from each tank. At the end of the experiment, the animals were individually anesthetized, weighted, and photographed with a digital camera. The total length, standard length and height were taken from each image through the open-source software IMAGE J (US National Institute of Health, available at http://rsb.info.nih.gov/ij/, accessed on 29 August 2019). The growth parameters were calculated using the following equations:

Weight gain $(\mathrm{WG})=$ final fish weight $\left(\mathrm{W}_{\mathrm{f}}\right)-$ initial fish weight $\left(\mathrm{W}_{\mathrm{i}}\right)$;

Daily growth rate $(\mathrm{DGR})=\left(\mathrm{W}_{\mathrm{f}}-\mathrm{W}_{\mathrm{i}}\right) / \mathrm{T}$, where $\mathrm{T}$ represents the time of the study in days; Specific growth rate $(S G R)=\left(\left(\ln W_{\mathrm{f}}-\ln \mathrm{W}_{\mathrm{i}} / \mathrm{T}\right)\right) \times 100$;

Condition factor index $(\mathrm{K})=\left(\mathrm{W} \times \mathrm{L}^{-3}\right) \times 10^{3}$, where $\mathrm{W}$ is mass in milligrams and $\mathrm{L}$ is standard length in millimeters.

\subsection{RNA Extraction and cDNA Synthesis}

All samples were collected at each sampling time, prior to morning feeding. For quantitative PCR assays, eight pooled samples of ten larvae were taken at the beginning of the experiment, and two juveniles ( $60 \mathrm{dph})$ from each tank (eight specimens per treatment) were taken after 30 days of experiment. At the end of experiment (60 days of experiment), three adult animals (90 dph) from each tank (12 specimens per treatment) were randomly sampled and sacrificed for collecting the liver (to assess the expression of the genes related to immune and stress responses), muscle (to assess the expression of the genes related to muscle growth), and gut (to assess the expression of genes related to chitin hydrolysis) for subsequent extraction of total RNA. All samples were stored in RNAlater (Sigma-Aldrich Milano, Italy) according to manufacturer's instructions. Total RNA was extracted from samples using QIAzol lysis reagent (Qiagen, Milano, Italy), according to manufacturer's instructions. RNase-free DNase (Qiagen, Milano, Italy) was used to eliminate contaminating genomic DNA. RNA quantity, purity, and integrity were verified 
by both electrophoresis on $1.0 \%$ agarose gel and UV absorbance measurements at 260 and $280 \mathrm{~nm}$ (NanoDrop 2000, Thermo Scientific, Wilmingtom, MA). One microgram total RNA was reverse transcribed into cDNA by QuantiTect reverse transcription kit (Qiagen) according to the manufacturer's protocol.

\subsection{Quantitative Gene Expression ( $q P C R$ )}

The cDNA samples were used to evaluate the mRNA levels of selected genes associated with different pathways by quantitative real time PCR. Transcripts of the genes related to muscular growth, namely insulin-like growth factor 1 (igf-1) and 2 (igf-2), myostatin $b$ (mstnb), myogenic differentiation 1 (myod1), myogenin (myog) and myogenic factor 5 (myf5), to immune and stress response-interleukin 1 beta (il1b), interleukin 6 (il6), tumor necrosis factor $\alpha$ (tnf $\alpha)$, heat-shock protein-70 (hsp70), glucocorticoid receptor (nr3c1) - as well as genes involved in the enzymatic hydrolysis of chitin—chitinase 2, 3 and 5 (chia.2, chia.3, chia.5) were quantified using specific qPCR primer sets (Table 2).

Table 2. Primer pair sequences, amplicon size, PCR efficiency (E), GenBank/Ensembl accession number, and reference related to quantitative real-time PCR analyzed genes.

\begin{tabular}{|c|c|c|c|c|c|}
\hline Gene Name & $\begin{array}{l}\text { Forward }\left(5^{\prime}-3^{\prime}\right) \\
\text { Reverse }\left(5^{\prime}-3^{\prime}\right)\end{array}$ & Size (bp) & E (\%) & GenBank & Reference \\
\hline$i g f-1$ & $\begin{array}{l}\text { GGCAAATCTCCACGATCTCTAC } \\
\text { CGGTTTCTCTTGTCTCTCTCAG }\end{array}$ & 198 & 105 & ENSDART00000004717.8 & {$[13]$} \\
\hline$i g f-2$ & $\begin{array}{l}\text { CGTGTGTGGAGAAGATGGCT } \\
\text { ACATCTCGCTCCGACTTCAC }\end{array}$ & 156 & 108 & ENSDART00000009642.7 & This study \\
\hline$m s t n b$ & $\begin{array}{l}\text { CGGACTGGACTGCGATGAG } \\
\text { AGATGGGTGTGGGGATACTTC }\end{array}$ & 174 & 97 & ENSDART00000100386.2 & [13] \\
\hline myod1 & $\begin{array}{l}\text { AGACGAGAAGACGGAACAGC } \\
\text { CACGATGCTGGACAGACAAT }\end{array}$ & 116 & 99 & NM_131262.2 & This study \\
\hline myog & $\begin{array}{l}\text { CACATACTGGGGTGTCGTCC } \\
\text { GCCTCTGTTCCCGTTATGCT }\end{array}$ & 199 & 94 & ENSDART00000014062.7 & This study \\
\hline$m y f 5$ & $\begin{array}{l}\text { GCAGTGTTTGTCCAGCATCG } \\
\text { GCAAGCAGTGTGAGTAAGCGT }\end{array}$ & 192 & 102 & ENSDART00000112035.2 & This study \\
\hline$i l 1 b$ & $\begin{array}{l}\text { AGGCTGGAGATGTGGACTTC } \\
\text { GTGGATTGGGGTTTGATGTG }\end{array}$ & 95 & 94 & ENSDART00000185837 & [13] \\
\hline il6 & $\begin{array}{l}\text { ATGACGGCATTTGAAGGGGT } \\
\text { TCAGGACGCTGTAGATTCGC }\end{array}$ & 115 & 94 & ENSDART00000166112.2 & This study \\
\hline $\operatorname{tnf} \alpha$ & $\begin{array}{l}\text { GGAGAGTTGCCTTTACCGCT } \\
\text { TGTTGATTGCCCTGGGTCTT }\end{array}$ & 155 & 90 & ENSDART00000025847.9 & This study \\
\hline hsp70 & $\begin{array}{l}\text { TCCTGACCATTGAAGACGGC } \\
\text { GCCCTCTTGTTCTGACTGATGT }\end{array}$ & 151 & 100 & ENSDART00000124762.3 & This study \\
\hline$n r 3 c 1$ & $\begin{array}{l}\text { CTGTGTTTCGCTCCAGACCT } \\
\text { TCTTCAACCCATCCTTCGG }\end{array}$ & 184 & 94 & ENSDART00000181179.1 & This study \\
\hline chia.2 & $\begin{array}{l}\text { AGTGCTGCTGTATCTGCTGG } \\
\text { CTGTGAATCGCTCCCAAGTT }\end{array}$ & 127 & 90 & ENSDART00000164702.2 & This study \\
\hline chia.3 & $\begin{array}{l}\text { TGCCTCCAATGCCTTCAACT } \\
\text { TCCATCTGGCTTCCCATTACA }\end{array}$ & 122 & 101 & ENSDART00000067817.6 & This study \\
\hline chia.5 & $\begin{array}{l}\text { CACGGCTCACAGGACAACAT } \\
\text { CATACGCAGCAAAGCCCAT }\end{array}$ & 160 & 105 & NM_001110041 & This study \\
\hline $\operatorname{arp}$ & $\begin{array}{l}\text { CATCTCGCCCTTCTCCTACG } \\
\text { GCAAGAGTTGGGTAGCCGAT }\end{array}$ & 168 & 101 & AF134852 & This study \\
\hline rpl13 & $\begin{array}{l}\text { ATCTCTGTTGACTCACGCCG } \\
\text { GTGCGGTATTCCTTCAGCCT }\end{array}$ & 80 & 103 & ENSDART00000176368.2 & This study \\
\hline ef1- $\alpha$ & $\begin{array}{l}\text { CCTGCCAATGTAACCACTGA } \\
\text { TGATGACCTGAGCGTTGAAG }\end{array}$ & 193 & 95 & NM_131263 & This study \\
\hline
\end{tabular}

PCR reactions were performed with SYBER Green chemistry (Qiagen) in the RotorGene Q 2plex Hrm thermocycler (Qiagen) and twenty-fold diluted cDNA samples (six biological replicates for each experimental diet and sampling time) were run in duplicate 
together with no template and minus reverse transcriptase controls. The PCR efficiency was determined performing, for each gene, a five-point standard curve of a 5-fold dilution series (1:1 to 1:32) from pooled RNA as described by Giannetto et al. [29]. The normalization factor was calculated by the geNorm software (http:/ / medgen.ugent.be/ jvdesomp/genorm/, accessed on 16 October 2020) from the two most stable reference genes among acid ribosomal phosphoprotein (arp), ribosomal protein L13 (rpl13), and elongation factor $1 \alpha$ (ef1- $\alpha$ ) in order to correct the raw target gene data, as described by Nagasawa et al. [30]. The specificity of each reaction was evaluated by dissociation curve analysis that showed a single pick in each run.

\subsection{Statistical Analysis}

Growth parameters data were subjected to one-way analysis of variance (ANOVA). Post-hoc comparisons were made by Tukey's test. Data were expressed as mean \pm S.E. The differences in transcript levels of tested genes among the experimental groups of fish fed with the three diets were assessed by analysis of variance followed by Student-NewmanKeuls post-hoc tests. Normality and variance homogeneity were previously checked and a significance level of $5 \%$ was adopted in every case. Data were expressed as mean \pm S.D. Statistical analyses were performed using the SAS software [31].

\section{Results}

\subsection{Survival and Growth Performance}

At the end of the experiment, no significant differences were observed in the survival rates among the dietary treatments ( $p>0.05$; Table 3$)$. All feeds were utilized in the trial initially floated and were readily consumed by zebrafish.

Table 3. Survival rate and growth parameters of zebrafish (Danio rerio) fed with experimental diets (control, $\mathrm{V}$ instar, and prepupae) for 60 days.

\begin{tabular}{cccc}
\hline Treatment & Control & V Instar & Prepupae \\
\hline Survival rate (\%) & $92.50 \pm 3.23^{\mathrm{a}}$ & $93.75 \pm 4.73^{\mathrm{a}}$ & $96.25 \pm 2.39^{\mathrm{a}}$ \\
Final total length (mm) & $24.11 \pm 0.64^{\mathrm{b}}$ & $26.08 \pm 0.98^{\mathrm{ab}}$ & $28.46 \pm 0.38^{\mathrm{a}}$ \\
Final standard length (mm) & $20.14 \pm 0.63^{\mathrm{b}}$ & $21.84 \pm 0.68^{\mathrm{ab}}$ & $23.08 \pm 0.26^{\mathrm{a}}$ \\
Height (mm) & $5.38 \pm 0.16^{\mathrm{b}}$ & $5.71 \pm 0.12^{\mathrm{ab}}$ & $6.11 \pm 0.09^{\mathrm{a}}$ \\
Final body weight (mg) & $132.99 \pm 10.39^{\mathrm{b}}$ & $159.41 \pm 13.58^{\mathrm{ab}}$ & $189.70 \pm 5.00^{\mathrm{a}}$ \\
Weight gain (mg) & $127.99 \pm 10.39^{\mathrm{b}}$ & $154.41 \pm 13.58^{\mathrm{ab}}$ & $184.70 \pm 5.39^{\mathrm{a}}$ \\
Daily growth rate (mg/day) & $2.13 \pm 0.17^{\mathrm{b}}$ & $2.57 \pm 0.23^{\mathrm{ab}}$ & $3.08 \pm 0.08^{\mathrm{a}}$ \\
Specific growth rate & $5.37 \pm 0.12^{\mathrm{b}}$ & $5.67 \pm 0.14^{\mathrm{ab}}$ & $5.97 \pm 0.04^{\mathrm{a}}$ \\
Condition factor index & $1.55 \pm 0.02^{\mathrm{a}}$ & $1.39 \pm 0.03^{\mathrm{b}}$ & $1.46 \pm 0.03^{\mathrm{ab}}$ \\
\hline
\end{tabular}

Data are expressed as mean \pm S.E. Different letters indicate significant differences among treatments $(p<0.05 ;$ ANOVA).

During the first 30 days of experiment, there were no weight differences among treatments ( $p>0.05$; Figure S1). However, at the end of the experiment, significant differences were observed in all growth parameters among the treatments. Zebrafish fed with prepupae treatment had significantly higher total length, standard length, height, final body weight, weight gain, daily growth rate, and specific growth rate compared to control treatment $(p<0.05$; Table 3$)$, but no significant difference when compared to $\mathrm{V}$ instar treatment ( $p>0.05$; Table 3$)$ was found. For all of these parameters, no significant differences were observed between $\mathrm{V}$ instar and control $(p>0.05$; Table 3$)$. Regarding the condition factor index, fish from control group showed a higher value than $\mathrm{V}$ instar group, but no differences were observed between control and prepupae treatment (Table 3).

\subsection{Quantitative Gene Expression}

\subsubsection{Muscle Growth}

Quantitative gene expression analysis showed that the transcript levels of the genes involved in fish growth were peculiarly modulated by the two BSF diets (Figure 1). The 
major effects of BSF inclusion on the gene expression were evident in adult zebrafish $(90 \mathrm{dph})$ and to a lesser extent in juveniles (60 dph).

A

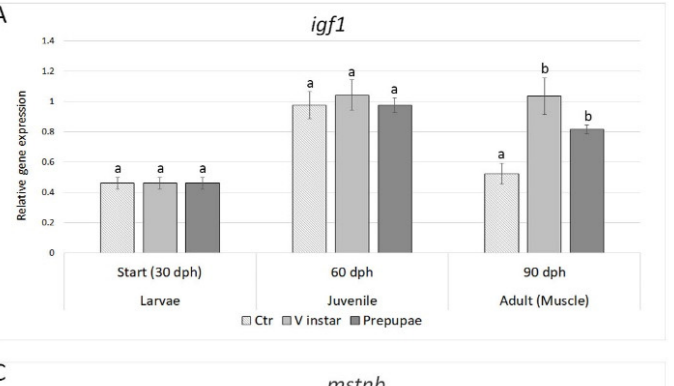

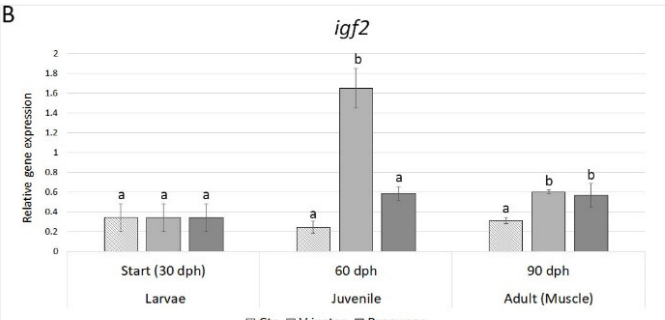

D

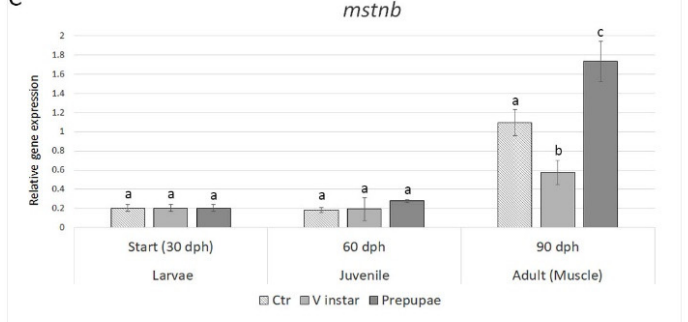

E
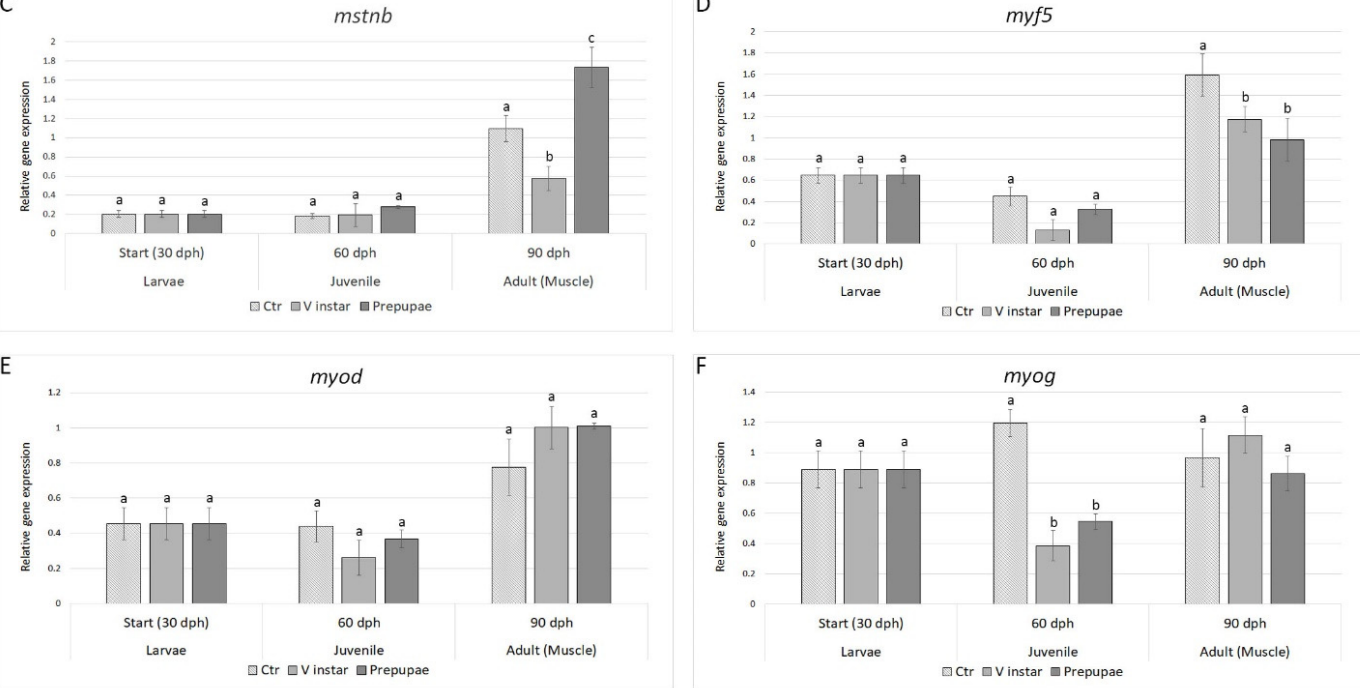

F

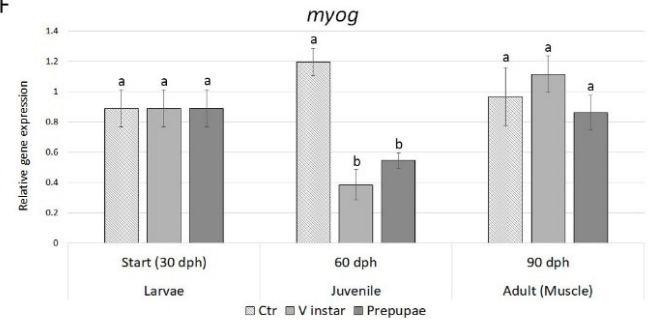

Figure 1. Expression profiles of genes involved in growth: (A) igf1, (B) igf2, (C) mstnb, (D) myf5, (E) myod, and (F) myog. Relative mRNA levels were evaluated in zebrafish larvae ( $30 \mathrm{dph})$, juveniles ( $60 \mathrm{dph})$, and adults $(90 \mathrm{dph})$ fed with $V$ instar and prepupae diets compared to controls fed with a diet containing fishmeal as the main protein source. Data are expressed as mean \pm S.D. $(n=6)$. Different letters indicate significant differences in transcript levels among experimental groups within the same sampling time $(p<0.05)$.

Although the igf1 gene expression did not show significant differences among the three experimental groups at $60 \mathrm{dph}$ (juvenile), the different BSF diets significantly influenced the ifg1 expression at $90 \mathrm{dph}$ (adult) with both $\mathrm{V}$ instar and prepupae groups showing significantly higher mRNA levels (2- and 1.6-fold, respectively) with respect to control group ( $p<0.001$; Figure 1A).

$\mathrm{V}$ instar meal fed zebrafish showed significantly higher igf2 gene expression at $60 \mathrm{dph}$ with respect to control (5.3-fold; $p<0.05)$. At $90 \mathrm{dph}$, both $\mathrm{V}$ instar and prepupae groups showed significantly higher igf2 gene expression (about 2-fold for both treatment groups) with respect to control ( $p<0.05$; Figure 1B).

The mstnb transcript levels did not show significant differences in both the experimental groups with respect to control at $60 \mathrm{dph}$ (Figure 1C). On the contrary, at the adult stage, the mstnb gene expression levels were significantly lower (1.8-fold) in the V instar group $(p<0.05)$ and significantly higher $(1.5$-fold $)$ in prepupae group $(p<0.05)$, with respect to control. The opposite trend of mstnb gene expression in adults indicated that the different BSF diets could also modulate the levels of this growth factor (Figure 1C).

The myf5 gene expression pattern did not show significant differences in both treatment groups with respect to control at $60 \mathrm{dph}$, while both $\mathrm{V}$ instar and prepupae groups showed a significant decrease in myf5 gene expression as compared to control group at $90 \mathrm{dph}(p<0.05)$, with levels 1.3-fold (V instar) and 1.6-fold (prepupae) lower in BSF-fed zebrafish, with respect to specimens fed with control diet (Figure 1D). 
The myod gene expression did not show significant differences among the three experimental groups at all the sampling times as the transcript levels in both V instar and prepupae groups were comparable to control in zebrafish juvenile and adults (Figure 1E).

Finally, the myog gene expression did not show differences in both $\mathrm{V}$ instar and prepupae groups, with respect to control at $90 \mathrm{dph}$ (Figure 1F). However, myog transcript levels were significantly lower in both experimental groups, with respect to control at $60 \mathrm{dph}$, with a significant downregulation of myog expression in V instar (3-fold) and prepupae groups $(2.2$-fold), respectively $(p<0.05)$.

\subsubsection{Enzymatic Hydrolysis of Chitin}

The expression of the genes involved in enzymatic hydrolysis of chitin (chia.2, chia.3, and chia.5) was modulated by the different BSF diets exclusively in adult zebrafish (Figure 2). The transcript levels of all the investigated chitinases were significantly upregulated in fish fed BSF-prepupae ( $p<0.001$ ) with values 2.5- (chia.2), 3.1- (chia.3), and 3.5-fold (chia.5) higher, with respect to control. Noteworthy, V instar BSF diet did not induce significant differences in chitinase genes expression in both juvenile and adult zebrafish.

A

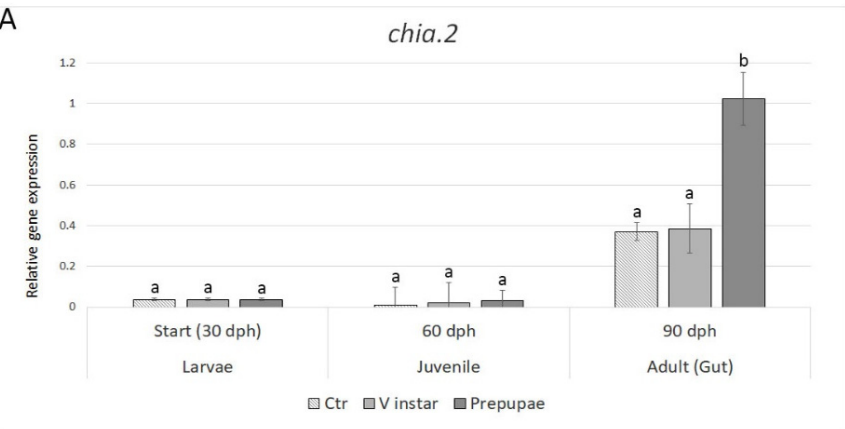

B

chia.3
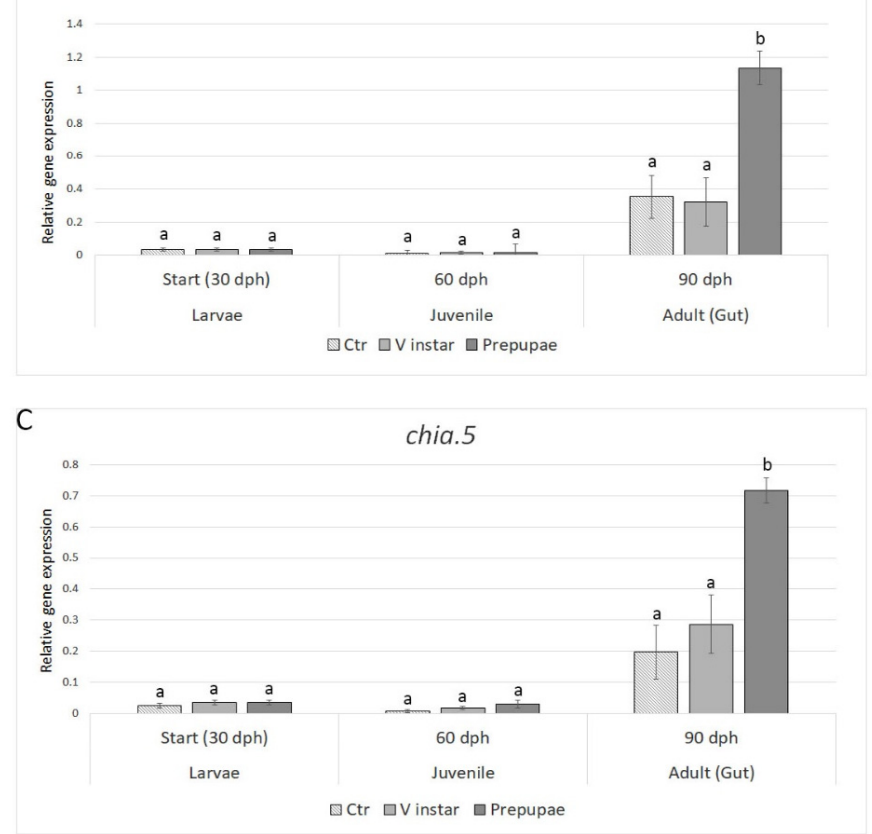

Figure 2. Expression profiles of genes associated with chitin hydrolysis: (A) chia.2, (B) chia.3, and (C) chia.5. Relative mRNA levels were evaluated in zebrafish larvae (30 dph), juveniles (60 dph), and adults ( $90 \mathrm{dph}$ ) fed with $\mathrm{V}$ instar and prepupae diets compared to controls fed with a diet containing fishmeal as the main protein source. Data are expressed as mean \pm S.D. $(n=6)$. Different letters indicate significant differences in transcript levels among experimental groups within the same sampling time $(p<0.05)$. 


\subsubsection{Immune Response}

The analysis of the expression levels of genes involved in immune response (il1b, il6, and $t n f a$ ) showed that $i l 1 b$ and $i l 6$ were upregulated in both treatment groups (with respect to control) in juveniles, while their transcript levels did not show any significant difference in adults among the three experimental groups (Figure 3A,B). The tnfa gene expression was affected by the different BSF diets exclusively in adult zebrafish fed BSF-V instar with values 4-fold higher with respect to control (Figure 3C). Prepupae diet did not affect $\operatorname{tnfa}$ gene expression in either juveniles or adults.

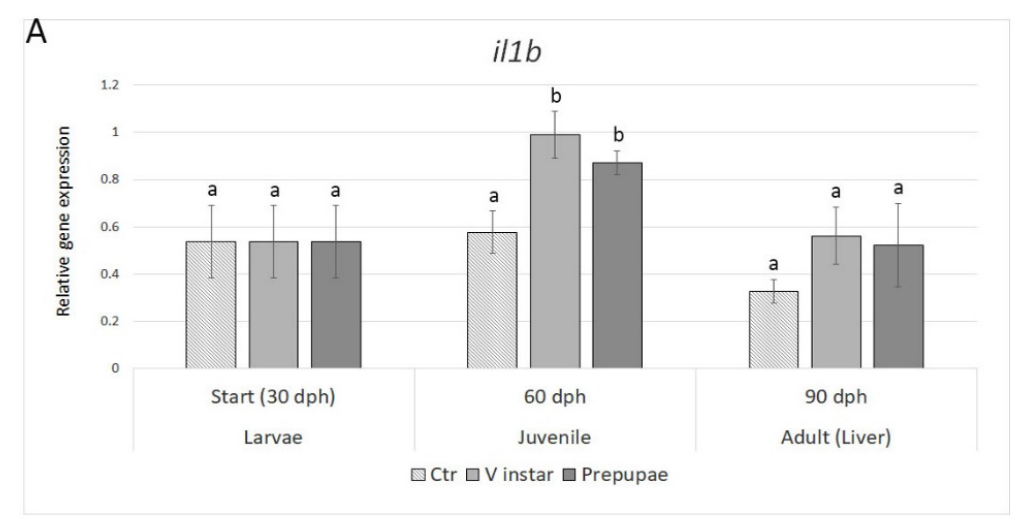

\section{B}

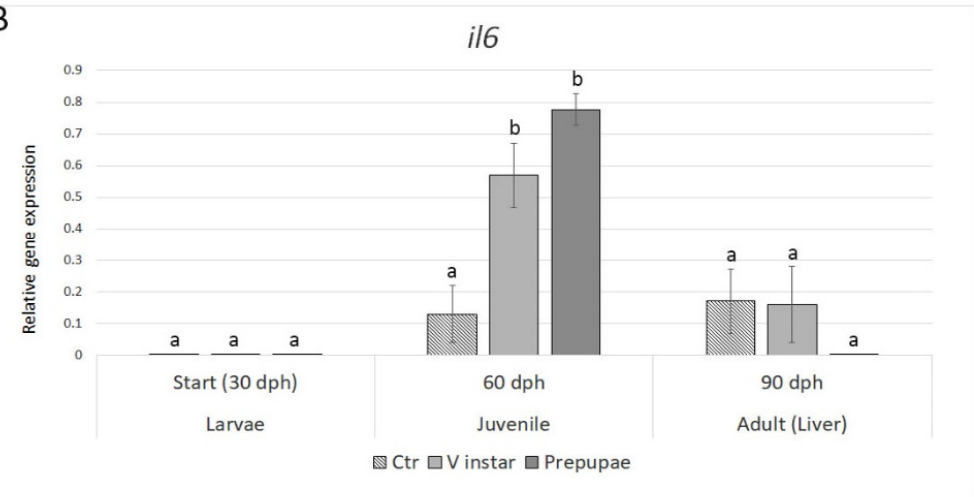

C

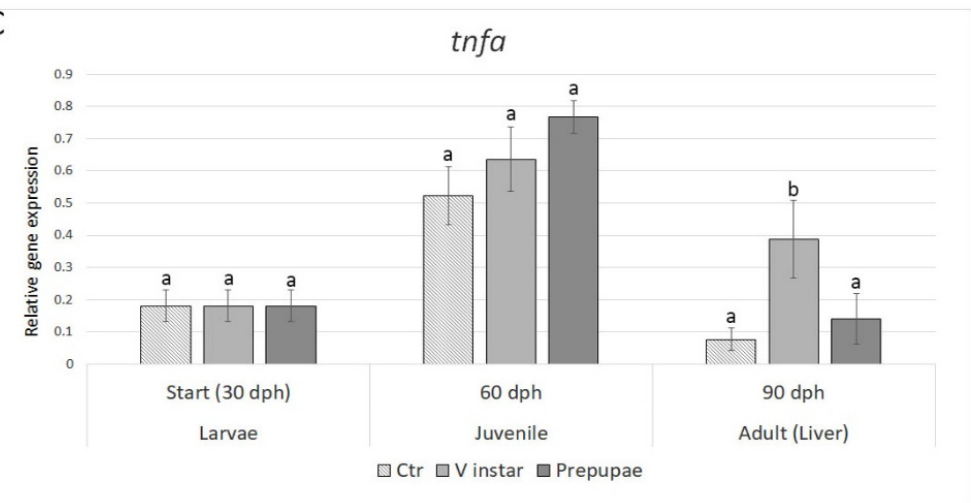

Figure 3. Expression profiles of genes involved in immune response (A) $i l 1 b$, (B) il6, and (C) tnfa. Relative mRNA levels were evaluated in zebrafish larvae $(30 \mathrm{dph})$, juveniles $(60 \mathrm{dph})$, and adults $(90 \mathrm{dph}$ ) fed with $\mathrm{V}$ instar and prepupae diets compared to controls fed with a diet containing fishmeal as the main protein source. Data are expressed as mean \pm S.D. $(n=6)$. Different letters indicate significant differences in transcript levels among experimental groups within the same sampling time $(p<0.05)$. 


\subsubsection{Stress Response}

Transcript levels of the selected stress markers were modulated by the different BSF diets exclusively in juvenile zebrafish (Figure 4). On the contrary, both $h s p 70$ and $n r 3 c 1$ gene expression levels did not show any significant differences in $\mathrm{V}$ instar and prepupae groups, with respect to control in adult fish (90 dph).

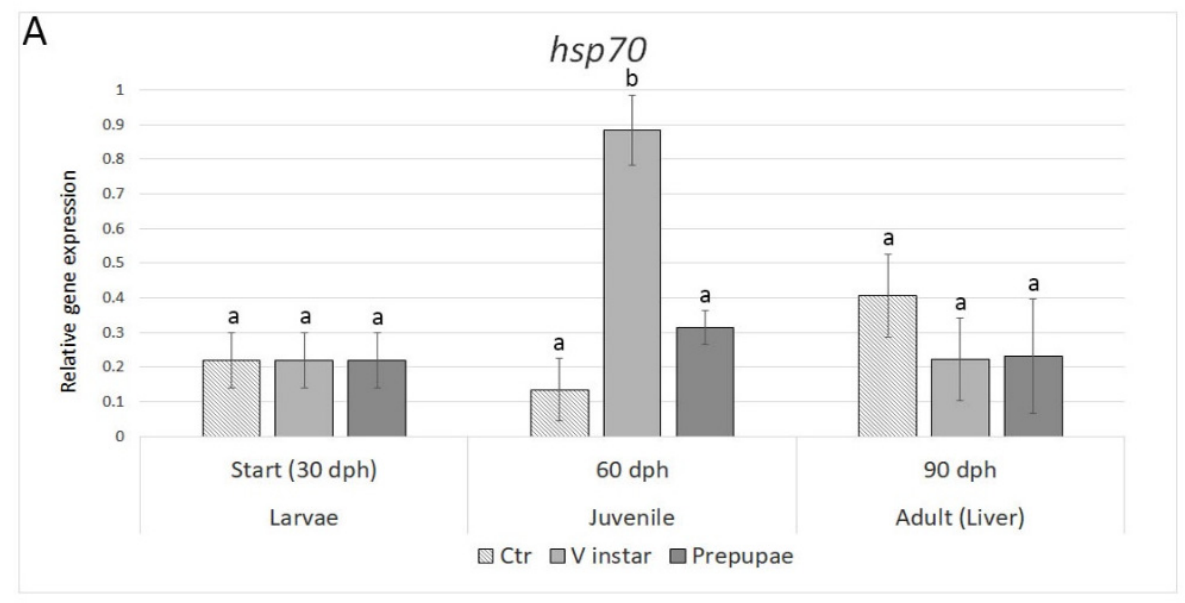

B

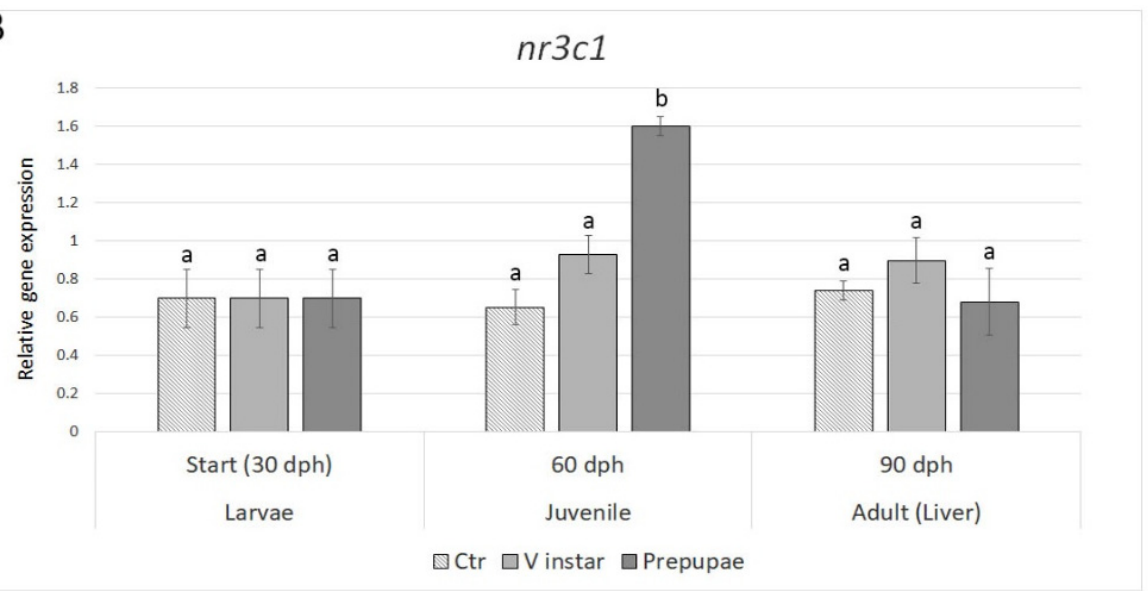

Figure 4. Expression profiles of stress-related genes (A) $h s p 70$ and (B) $n r 3 c 1$. Relative mRNA levels were evaluated in zebrafish larvae ( $30 \mathrm{dph})$, juveniles $(60 \mathrm{dph})$, and adults $(90 \mathrm{dph})$ fed with V instar and prepupae diets compared to controls fed with a diet containing fishmeal as the main protein source. Data are expressed as mean \pm S.D. $(n=6)$. Different letters indicate significant differences in transcript levels among experimental groups within the same sampling time $(p<0.05)$.

\section{Discussion}

Among several insect species tested in aquafeeds, BSF is one of the most promising because it shows an essential amino acid profile similar to fishmeal [4]. This study demonstrated that the total substitution of fishmeal with two different BSF meals (obtained from two BSF developmental stages, i.e., $V$ instar larvae and prepupae) in zebrafish diet do not adversely affect growth performances and wellness. The inclusion of defatted $\mathrm{V}$ instar larvae and defatted prepupae meals induced a positive effect on growth parameters. Although recent literature has reported contrasting data on the effect of insect inclusion in fish diets [32], the long-term trial here evaluated showed the beneficial role of defatted BSF meals in zebrafish diet.

Previous studies showed marked differences on fatty acid and amino acid profiles between the larval and prepupae stages in BSF [14-16]. Recent studies on zebrafish have demonstrated that diets containing higher levels than $50 \%$ of inclusion of full-fat prepupae meal negatively affect the growth and induce hepatic steatosis, microbiota modification, 
higher lipid content, fatty acid modification, and higher expression of immune response markers $[13,33]$. According to authors, all of these negative effects could be related to fatty acid imbalance coming from BSF meal. It is known that the quantity of proteins and lipids can vary in BSF according to the rearing conditions, mainly the substrate used to feed the larvae. While the amino acid profile is less affected, the fatty acid composition depends greatly on the feed source [34,35]. The different findings could rely on the defatted BSF meal used in the present study, thus suggesting that this formulated diet can mitigate the imbalance HUFA/SFA (Highly Unsaturated Fatty Acid/Saturated Fatty Acid) characterizing insect meals and the subsequent negative effects previously reported $[13,33]$. Belghit et al. [10], also working with defatted insect meal, found that fish meal replacement with BSF up to $100 \%$ did not determine a decreased growth of Atlantic salmon (Salmo salar), suggesting BSF as a good alternative protein source for this species.

The biometric data were fully supported by the gene expression analysis of growth factors and myogenic regulatory factors. Although the insulin-like growth factors (igfs) are involved in several cellular process, they participate in neuroendocrine growth control with a principal role in regulation of somatic growth; their expression in muscle tissue may locally induce the expression of myogenic factors that in turn promote muscle growth [36]. Interestingly, gene expression of both igf1 and igf 2 in muscle tissue showed an upregulation in fish fed with BSF meal, supporting the growth parameters registered during the experiment. Surprisingly, the igf2 mRNA level was higher in juvenile zebrafish fed with V instar BSF meal, in respect to both control and to the prepupae meal. Gabillard et al. [37] demonstrated that the gene expression of $i g f 1$ and igf 2 in fish are dependent on feeding regime; our results on igf2 expression in juvenile zebrafish suggest that $V$ instar and prepupae BSF meals had different effects on fish growth, probably due to their different nutritional values, as previously demonstrated $[15,16]$.

Besides insulin-like growth factors, other key factors regulate fish growth. In particular, muscle growth is modulated by myogenic regulatory factors (MRFs) and myostatin-a negative endogenous regulator-that finely control the process until the adult. Although the effect of different diets on myogenesis has been poorly investigated, the few published studies showed that the nutrient supply could influence the expression of the genes coding for myogenic factors myf5, myod, and myog, thus orchestrating the process of skeletal myogenesis [38]. The observed gene expression patterns in zebrafish exposed to the two different BSF-based diets evidenced that the maintenance of fish growth is controlled by the differential regulation of precise muscle growth-related genes in juveniles and adults. While neither the $\mathrm{V}$ instar nor the prepupae meals were able to modulate the expression of myod1, at the juvenile or the adult stage, the modulation of the expression of myf5 and mstnb in adults, as well as myog in juveniles, strongly suggests that the different nutritional properties of the two BSF meals may modulate the growth response in fish.

One of the major controversial issues in using insect-based meals in fish diet is the high level of chitin, the major constituent of the exoskeleton. It is a common idea that high chitin level inclusion in aquafeeds can negatively influence the digestibility as well as the utilization of nutrients; thus, compromising fish growth and health [4,39-44]. Previous studies reported the different chitinolytic activity of several fish species [39,45-47]. Our results clearly showed that the gene expression levels of chitinases were remarkably high in adult fish only. Moreover, it is worthy to note that the gene expression of all chitinases was much higher in fish fed with BSF prepupae in respect to fish fed with BSF V instar, with the latter comparable to control. These data suggest that the chitinolytic activity in zebrafish is strictly dependent on the BSF developmental stage used as feed, having prepupae meal higher chitin content compared to $V$ instar meal [15]. In our opinion, these findings give important knowledge on the inclusion of insect in aquafeeds and open innovative scenarios for selecting the appropriate BSF-based diet for different fish species or developmental stages, thus ensuring a normal feed intake and growth in those species where the chitinolytic activity is scarce or lacking. 
Several studies have investigated the effects of chitin on the immune system to elucidate its potential as an immunostimulatory additive for fish feed [48]. In general, the inclusion of chitin at low levels (from $0.01 \%$ to $2 \%$ ) in diets for fish, generally activates the innate immunity $[42,49,50]$. Moreover, studies have investigated the effect of dietary insect meals on the immune system in fish. In yellow catfish (Pelteobagrus fulvidraco), a diet with $25 \%$ substitution of fishmeal with BSF larvae meal protein enhanced the immunocompetence of the fish [51]. In Atlantic salmon, the total replacement of fishmeal with BSF larvae meal had no effect on the transcription of pro-inflammatory genes in the head kidney cells; however, an effect on the transcription of antioxidant and stress related genes in the leukocytes was observed [52]. In the present study, the levels of chitin were $6.31 \%$ and $7.22 \%$ in defatted $\mathrm{V}$ instar larvae and defatted prepupae meals, respectively. These levels of chitin in the BSF diets might have an impact on the modulation of the expression of interleukins (il1 $b$ and $i l 6$ ) in juveniles, but not in adult fish; on the contrary, tnfa expression in adults was modulated only by BSF V instar meal, showing a peculiar response to the different BSF meals.

The effects of different BSF meals on zebrafish wellness were evaluated measuring the expression of stress-related genes ( $h s p 70$ and $n r 3 c 1$ ). Both genes were modulated by the different BSF diets exclusively in juvenile zebrafish; however, no differences were observed among the three treatments in adult fish $(90 \mathrm{dph})$, showing that both BSF diets had no negative effects on adult fish. This result is in accordance with Zarantoniello et al. [13], where the effects of a full fat BSF meal inclusion of up to $50 \%$ was evaluated in 6-month adult zebrafish.

The results obtained from the zebrafish model organism can be useful for understanding the physiological and molecular responses of fish to insect-based diets that could be common to most aquaculture species. Indeed, zebrafish share the same or similar physiological response, besides developmental mechanisms and morphological features with many aquaculture species [13], thus providing useful information about the possible effects of BSF inclusion as feed ingredient in conventional aquaculture.

Taken together, our findings demonstrate that the two BSF developmental stages used as meal in zebrafish diets have different effects on fish growth and peculiar effects on immune response and modulation of chitinases. Therefore, 100\% of defatted BSF V instar or prepupae meal inclusion in the zebrafish diet could overcome the limitations of using fishmeal in aquafeeds; thus, suggesting the intriguing perspective of using defatted BSFbased meals in feed formulation as valuable and sustainable alternative protein sources for relevant aquaculture fish species.

Noteworthy, the herein tested BSF meals represent the larvae and prepupae biomass obtained through the bioconversion of vegetable waste; thus, highlighting the great potential of $H$. illucens in the waste valorization process, a new agri-food biotechnology to obtain high value nutritional resources in a circular economy context.

\section{Conclusions}

Our results indicate that fishmeal can be totally replaced with defatted BSF meals in diets for zebrafish. Particularly, the defatted BSF prepupae meal can promote zebrafish growth that, in turn, is supported by myogenesis-related genes expression. In addition, this study revealed that the expression of the genes involved in enzymatic hydrolysis of chitin (chia.2, chia.3, and chia.5) could be modulated by BSF diets, particularly in adult zebrafish fed BSF prepupae. Finally, the expression of genes related to stress and immune response indicate that diets containing defatted BSF meals do not impair the wellness of fish. Thus, our results suggest that BSF defatted V instar or prepupae meals are promising ingredients for the replacement of fishmeal in aquafeeds. 
Supplementary Materials: The following are available online at https:/ / www.mdpi.com/2076-2 615/11/3/720/s1. Figure S1: weight of zebrafish (Danio rerio) fed with experimental diets (control, V-instar, and prepupae) throughout of experiment.

Author Contributions: Conceptualization, C.F.C.L., F.A.P., G.T.B. and A.G.; methodology, C.F.C.L., F.A.P., G.T.B., A.L.B., B.E.R.D., J.C.V.V. and K.C.D.; formal analysis, C.F.C.L., K.R., S.O. and A.G.; investigation, C.F.C.L., F.A.P., G.T.B., A.L.B., B.E.R.D., J.C.V.V., K.C.D., S.O. and A.G.; resources, D.S.; data curation, K.R., S.O. and A.G.; writing-original draft preparation, C.F.C.L., F.A.P., G.T.B.; S.O. and A.G.; writing-review and editing, A.G. All authors have read and agreed to the published version of the manuscript.

Funding: This research was funded by the University of Messina, Finanziamento delle Attività Base di Ricerca, 2017.

Institutional Review Board Statement: The study was conducted according to the approval of the Ethics Committee for Animal Use (CEUA) of the Federal University of Pampa and registered according to protocol 056/2019.

Informed Consent Statement: Informed consent was obtained from all subjects involved in the study.

Data Availability Statement: The data presented in this study are available within the article and/or its supplementary materials.

Conflicts of Interest: The authors declare no conflict of interest.

\section{References}

1. FAO. The State of World Fisheries and Aquaculture 2020. Sustainability in action. Rome. Available online: http://www.fao.org/ documents/card/en/c/ca9229en (accessed on 7 July 2020).

2. Daniel, N. A review on replacing fish meal in aqua feeds using plant protein sources. Int. J. Fish. Aquat. Stud. $2018,6,164-179$.

3. Hua, K.; Cobcroft, J.M.; Cole, A.; Condon, K.; Jerry, D.R.; Mangott, A.; Praeger, C.; Vucko, M.J.; Zeng, C.; Zenger, K.; et al. The future of aquatic protein: Implications for protein sources in aquaculture diets. One Earth 2019, 1, 316-329. [CrossRef]

4. Henry, M.; Gasco, L.; Piccolo, G.; Fountoulaki, E. Review on the use of insects in the diet of farmed fish: Past and future. Anim. Feed Sci. Tech. 2015, 203, 1-22. [CrossRef]

5. AAFCO (Association of American Feed Control Officials). AAFCO Midyear Meeting Agenda Book; Hyatt Regency: Savannah, GA, USA, 2019; p. 42.

6. Ramos-Elorduy, J.; González, E.A.; Hernández, A.R.; PINO, J.M. Use of Tenebrio molitor (Coleoptera: Tenebrionidae) to recycle organic wastes and as feed for broiler chickens. J. Econ. Entomol. 2002, 95, 214-220. [CrossRef] [PubMed]

7. Van Huis, A.; Van Itterbeeck, J.; Klunder, H.; Mertens, E.; Halloran, A.; Muir, G.; Vantomme, P. Edible Insects -Future Prospects for Food and Feed Security; Forestry Paper 171; FAO (Food and Agriculture Organization of the United Nations): Rome, Italy, 2013.

8. Chia, S.Y.; Tanga, C.M.; van Loon, J.J.A.; Dicke, M. Insects for sustainable animal feed: Inclusive business models involving smallholder farmers. Curr. Opin. Environ. Sustain. 2019, 41, 23-30. [CrossRef]

9. Abdel-Tawwab, M.; Khalil, R.H.; Metwally, A.A.; Shakweer, M.S.; Khallaf, M.A.; Abdel- Latif, H.M.R. Effects of black soldier fly (Hermetia illucens L.) larvae meal on growth performance, organs-somatic indices, body composition, and hemato-biochemical variables of European sea bass. Dicentrarchus Labrax. Aquac. 2020, 522, 735136. [CrossRef]

10. Belghit, I.; Liland, N.S.; Gjesdal, P.; Biancarosa, I.; Menchetti, E.; Li, Y.; Waagbø, R.; Krogdahl, Å.; Lock, E.J. Black soldier fly larvae meal can replace fish meal in diets of sea-water phase Atlantic salmon (Salmo salar). Aquaculture 2019, 503, 609-619. [CrossRef]

11. Fawole, F.J.; Adeoye, A.A.; Tiamiyu, L.O.; Ajala, K.I.; Obadara, S.O.; Ganiyu, I.O. Substituting fishmeal with Hermetia illucens in the diets of African catfish (Clarias gariepinus): Effects on growth, nutrient utilization, haematophysiological response, and oxidative stress biomarker. Aquaculture 2020, 518, 734849. [CrossRef]

12. Sealey, W.M.; Gaylord, T.G.; Barrows, F.T.; Tomberlin, J.K.; McGuire, M.A.; Ross, C.; St-Hilaire, S. Sensory Analysis of Rainbow Trout, Oncorhynchus mykiss, Fed Enriched Black Soldier Fly Prepupae, Hermetia illucens. J. World Aquac. Soc. 2011, 42, 34-45. [CrossRef]

13. Zarantoniello, M.; Randazzo, B.; Truzzi, C.; Giorgini, E.; Marcellucci, C.; Vargas-Abúndez, J.A.; Zimbelli, A.; Annibaldi, A.; Parisi, G.; Tulli, F.; et al. A six-months study on Black Soldier Fly (Hermetia illucens) based diets in zebrafish. Sci. Rep. 2019, 9, 8598. [CrossRef] [PubMed]

14. Liu, X.; Chen, X.; Wang, H.; Yang, Q.; Ur Rehman, K.; Li, W.; Cai, M.; Li, Q.; Mazza, L.; Zhang, J.; et al. Dynamic changes of nutrient composition throughout the entire life cycle of black soldier fly. PLoS ONE 2017, 12, e0182601. [CrossRef] [PubMed]

15. Giannetto, A.; Oliva, S.; Ceccon Lanes, C.F.; de Araújo Pedron, F.; Savastano, D.; Baviera, C.; Parrino, V.; Lo Paro, G.; Spanò, N.; Cappello, T.; et al. Hermetia illucens (Diptera: Stratiomydae) larvae and prepupae: Biomass production, fatty acid profile and expression of key genes involved in lipid metabolism. J. Biotechnol. 2020, 307, 44-54. [CrossRef] [PubMed] 
16. Giannetto, A.; Oliva, S.; Riolo, K.; Savastano, D.; Parrino, V.; Cappello, T.; Maisano, M.; Fasulo, S.; Mauceri, A. Waste Valorization via Hermetia Illucens to Produce Protein-Rich Biomass for Feed: Insight into the Critical Nutrient Taurine. Animals 2020, 10, 1710. [CrossRef] [PubMed]

17. Huyben, D.; Vidakovi 'c, A.; Werner Hallgren, S.; Langeland, M. High-throughput sequencing of gut microbiota in rainbow trout (Oncorhynchus mykiss) fed larval and pre-pupae stages of black soldier fly (Hermetia illucens). Aquaculture 2019, 500, 485-491. [CrossRef]

18. Zarantoniello, M.; Bruni, L.; Randazzo, B.; Vargas, A.; Gioacchini, G.; Truzzi, C.; Annibaldi, A.; Riolo, P.; Parisi, G.; Cardinaletti, G.; et al. Partial Dietary Inclusion of Hermetia illucens (Black Soldier Fly) Full-Fat Prepupae in Zebrafish Feed: Biometric, Histological, Biochemical, and Molecular Implications. Zebrafish 2018, 15, 519-532. [CrossRef] [PubMed]

19. Ulloa, P.E.; Iturra, P.; Neira, R.; Araneda, C. Zebrafish as a model organism for nutrition and growth: Towards comparative studies of nutritional genomics applied to aquacultured fishes. Rev. Fish Biol. Fisher. 2011, 21, 649-666. [CrossRef]

20. Kim, W.; Bae, S.; Park, H.; Park, K.; Lee, S.; Choi, Y.; Han, S.; Koh, Y.H. The Larval Age and Mouth Morphology of the Black Soldier Fly, Hermetia illucens (Diptera: Stratiomyidae). Int. J. Indust. Entomol. 2010, 21, 185-187.

21. Tomberlin, J.K.; Adler, P.H.; Myers, H.M. Development of the black soldier fly (Diptera: Stratiomyidae) in relation to temperature. Environ. Entomol. 2009, 38, 930-934. [CrossRef] [PubMed]

22. Fernandes, H.; Peres, H.; Carvalho, A.P. Dietary protein requeriment during juvenile growth of zebrafish (Danio rerio). Zebrafish 2016, 13, 548-555. [CrossRef] [PubMed]

23. AOAC-Association of Official Analytical Chemists. Official Methods of Analysis of the Association of the Analytical Chemists, 16th ed.; AOAC: Washington, DC, USA, 1995; p. 1025.

24. Bligh, E.G.; Dyer, W.J. A rapid method of total lipid extraction and purification. Can. J. Biochem. Phys. 1959, 37, 911-917. [CrossRef] [PubMed]

25. Van Soest, P.J.; Robertson, J.B.; Lewis, B.A. Methods for dietary fiber, neutral detergent fiber, and nonstarch polysaccharides in relation to animal nutrition. J. Dairy Sci. 1991, 74, 3583-3597. [CrossRef]

26. Finke, M.D. Complete Nutrient Content of Four Species of Feeder Insects. Zoo Biol. 2013, 32, 27-36. [CrossRef] [PubMed]

27. Westerfield, M. The Zebrafish Book: A Guide for the Laboratory Use of Zebrafish (Brachydanio rerio), 3rd ed.; University of Oregon Press: Eugene, OR, USA, 1995.

28. Grush, J.; Noakes, D.J.G.; Moccia, R.D. The efficacy of clove oil as an anesthetic for the zebrafish, Danio rerio (Hamilton). Zebrafish 2004, 1, 46-53. [CrossRef] [PubMed]

29. Giannetto, A.; Nagasawa, K.; Fasulo, S.; Fernandes, J.M.O. Influence of photoperiod on expression of DNA (cytosine-5) methyltransferases in Atlantic cod. Gene 2013, 519, 222-230. [CrossRef] [PubMed]

30. Nagasawa, K.; Giannetto, A.; Fernandes, J.M.O. Photoperiod influences growth and MLL (mixed-lineage leukaemia) expression in Atlantic cod. PLoS ONE 2012, 7, e36908. [CrossRef] [PubMed]

31. SAS Institute Inc. SAS®University Edition Quick Start Guide for Students with Visual Impairments; SAS Institute Inc.: Cary, NC, USA, 2018.

32. Hua, K. A meta-analysis of the effects of replacing fish meals with insect meals on growth performance of fish. Aquaculture 2021, 530, 735732. [CrossRef]

33. Zarantoniello, M.; Randazzo, B.; Gioacchini, G.; Truzzi, C.; Giorgini, E.; Riolo, P.; Gioia, G.; Bertolucci, C.; Osimani, A.; Cardinaletti, G.; et al. Zebrafish (Danio rerio) physiological and behavioural responses to insect-based diets: A multidisciplinary approach. Sci. Rep. 2020, 10, 10648. [CrossRef] [PubMed]

34. Tschirner, M.; Simon, A. Influence of different growing substrates and processing on the nutrient composition of black soldier fly larvae destined for animal feed. J. Insects Food Feed 2015, 1, 249-259. [CrossRef]

35. Spranghers, T.; Ottoboni, M.; Klootwijk, C.; Ovyn, A.; Deboosere, S.; De Meulenaer, B.; De Smet, S. Nutritional composition of black soldier fly (Hermetia illucens ) prepupae reared on different organic waste substrates. J. Sci. Food Agric. 2016, 97, $2594-2600$. [CrossRef] [PubMed]

36. Johnston, I.A.; Bower, N.I.; Macqueen, D.J. Growth and the regulation of myotomal muscle mass in teleost fish. J. Exp. Biol. 2011, 214, 1617-1628. [CrossRef] [PubMed]

37. Gabillard, J.C.; Kamangar, B.B.; Montserrat, N. Coordinated regulation of the GH/IGF system genes during refeeding in rainbow trout (Oncorhynchus mykiss). J. Endocrinol. 2006, 191, 15-24. [CrossRef] [PubMed]

38. Lavajoo, F.; Perelló-Amorós, m.; Vélez, E.J.; Sánchez-Moya, A.; Balbuena-Pecino, S.; Riera-Heredia, N.; Fernández-Borràs, J.; Blasco, J.; Navarro, I.; Capilla, E.; et al. Regulatory mechanisms involved in muscle and bone remodeling during refeeding in gilthead sea bream. Sci. Rep. 2020, 10, 1-14. [CrossRef] [PubMed]

39. Kroeckel, S.; Harjes, A.G.E.; Roth, I.; Katz, H.; Wuertz, S.; Susenbeth, A.; Schulz, C. When a turbot catches a fly: Evaluation of a pre-pupae meal of the Black Soldier Fly (Hermetia illucens) as fish meal substitute-Growth performance and chitin degradation in juvenile turbot (Psetta maxima). Aquaculture 2012, 364, 345-352. [CrossRef]

40. Shiau, S.Y.; Yu, Y.P. Dietary supplementation of chitin and chitosan depresses growth in tilapia, Oreochromis niloticus $\times$ O. aureus. Aquaculture 1999, 179, 439-446. [CrossRef]

41. Diener, S.; Zurbrügg, C.; Tockner, K. Conversion of organic material by black soldier fly larvae: Establishing optimal feeding rates. Waste Manag. Res. 2009, 27, 603-610. [CrossRef] [PubMed] 
42. Gopalakannan, A.; Arul, V. Immunomodulatory effects of dietary intake of chitin, chitosan and levamisole on the immune system of Cyprinus carpio and control of Aeromonas hydrophila infection in ponds. Aquaculture 2006, 255, 179-187. [CrossRef]

43. Hansen, A.C.; Rosenlund, G.; Karlsen, Ø.; Koppe, W.; Hemre, G.I. Total replacement of fish meal with plant proteins in diets for Atlantic cod (Gadus morhua L.) I-Effects on growth and protein retention. Aquaculture 2007, 272, 599-611. [CrossRef]

44. Rapatsa, M.M.; Moyo, N.A.G. Evaluation of Imbrasia belina meal as a fishmeal substitute in Oreochromis mossambicus diets: Growth performance, histological analysis and enzyme activity. Aquac. Rep. 2017, 5, 18-26. [CrossRef]

45. Fines, B.C.; Holt, G.J. Chitinase and apparent digestibility of chitin in the digestive tract of juvenile cobia, Rachycentron canadum. Aquaculture 2010, 303, 34-39. [CrossRef]

46. Danulat, E. The effects of various diets on chitinase and bglucosidase activities and the condition of cod, Gadus morhua (L.). J. Fish Biol. 1986, 28, 191-197. [CrossRef]

47. Lindsay, G.J.H.; Walton, M.J.; Adron, J.W.; Fletcher, T.C.; Cho, C.Y.; Cowey, C.B. The growth of rainbow trout (Salmo gairdneri) given diets containing chitin and its relationship to chitinolytic enzymes and chitin digestibility. Aquaculture 1984, 37, 315-334. [CrossRef]

48. Kamilya, D.; Khan, M.I.R. Chitin and chitosan as promising immunostimulant for aquaculture. In Handbook of Chitin and Chitosan, 1st ed.; Thomas, S., Pius, A., Gopi, S., Eds.; Elsevier: Amsterdã, The Netherlands, 2020; pp. 761-771. [CrossRef]

49. Esteban, M.A.; Mulero, V.; Cuesta, A.; Ortuño, J.; Meseguer, J. Effects of injecting chitin particles on the innate immune response of gilthead seabream (Sparus aurata L.). Fish Shellfish Immun. 2000, 10, 543-554. [CrossRef] [PubMed]

50. Harikrishnan, R.; Kim, J.S.; Balasundaram, C.; Heo, M.S. Dietary supplementation with chitin and chitosan on haematology and innate immune response in Epinephelus bruneus against Philasterides dicentrarchi. Exp. Parasitol. 2012, 131, 116-124. [CrossRef] [PubMed]

51. Xiao, X.; Jin, P.; Zheng, L.; Cai, M.; Yu, Z.; Yu, J.; Zhang, J. Effects of black soldier fly (Hermetia illucens) larvae meal protein as a fishmeal replacement on the growth and immune index of yellow catfish (Pelteobagrus fulvidraco). Aquac. Res. 2018, 1-9. [CrossRef]

52. Stenberg, O.K.; Holen, E.; Piemontese, L.; Liland, N.S.; Lock, E.J.; Espe, M.; Belghit, I. Effect of dietary replacement of fish meal with insect meal on in vitro bacterial and viral induced gene response in Atlantic salmon (Salmo salar) head kidney leukocytes. Fish Shellfish Immun. 2019, 91, 223-232. [CrossRef] [PubMed] 